\title{
Correspondence
}

http://dx.doi.org/10.11646/phytotaxa.177.3.8

\section{A new species of Neottia (Orchidaceae, Epidendroideae) from southwestern China}

\author{
XIAO-HUA JIN ${ }^{1}$ \\ ${ }^{I}$ State Key Laboratory of Systematic and Evolutionary Botany and Herbarium, Institute of Botany, Chinese Academy of Sciences, Nanx- \\ incun 20, Xiangshan, Beijing, 100093, China; e-mail: orchid@ibcas.ac.cn
}

\begin{abstract}
Neottia bicallosa, a new species from China, is described and illustrated. Neottia bicallosa is similar to Neottia karoana and N. microphylla, but differs from them by having oblong and erect lateral lobes with two fleshy calli between them, middle lobe elliptic and 3-lobed, and lateral lobules dentate.
\end{abstract}

Key words: China, Neottia bicallosa, new species, Orchidaceae

\section{Introduction}

Neottia s.1. Guettard (1754: 374), including Listera Brown (1813:201), consists of approximately 50 species, distributed mainly in northern temperate areas with a few species extending into alpine mountains in tropical Asia (Pridgeon et al. 2005; Pearce \& Cribb 2002; Chen 1999). This genus includes both autotrophic and mycoheterotrophic plants, characterized by having resupinate flowers, a more or less curved column, retrorse-inclined anthers, and two-sectile and naked pollinia.

There are about 35 species of Neottia in China, most of which are endemic to the alpine region in southwestern China (Chen 1999; Chen et al. 2009). During our fieldwork in this region from 2005 to 2010, a new species of Neottia, described below, was discovered.

\section{Taxonomic treatment}

Neottia bicallosa X.H. Jin, sp. nov. (Figs. 1-2)

Habitu N. karoana et N. microphylla subsimilis, sed lobis lateralibus oblongis, callis carnosis, lobo medio trilobo distinguenda.

Type:- CHINA. Xizhang (Tibet): Chayu County, east slope of Gaoligongshan Mountains, in the alpine grassland., 4100 m, 9 July 2008, DLJ-ET (Dulongjiang Expedition Team) 1736 (holotype PE!).

Autotrophic plants, 2-5 cm tall. Roots $1 \mathrm{~mm}$ in diam. Stem with several sheaths at base. Leaves 2, borne on ground, opposite, ovate, acute, $0.9-1 \times 0.8-0.9 \mathrm{~cm}$. Inflorescence $4-5 \mathrm{~cm}$ long, pubescent. Floral bract lanceolate, 0.5 $\mathrm{cm}$ long. Ovary and pedicel 1.5-3.5 mm long, glabrous, ovary fusiform. Dorsal sepal elliptic, 1 -veined, obtuse, $2 \times$ $0.8 \mathrm{~mm}$; lateral sepals slightly oblique, 1 -veined, obtuse, $3 \times 1 \mathrm{~mm}$; petals elliptic, 1 -veined, obtuse, $2 \times 0.8 \mathrm{~mm}$; lip rhombic, 3-lobed, $2 \times 3 \mathrm{~mm}$; lateral lobes erect, base with two fleshy thickened calli between them, semi-orbicular, $0.3 \mathrm{~mm}$ long; middle lobes 3-lobed, lobules dentate; column erect, $0.2 \mathrm{~mm}$.

Distribution and Habitat:- This new species usually grows on rocks in humid alpine grassland with elevation of 4,000-4,200 m. It is one of a few orchids recorded in elevation more than 4,000 m in China. During our fieldwork in Eastern Himalayas in 2013, two additional populations of this species were discovered, one in Gongshan County, Yunnan Province, the other in Chayu County, Xizang Autonomous Region. Both populations are far from any direct threats. Hence, this new species should be considered as 'Least Concern' according to IUCN Red List Categories and Criteria (IUCN, 2001). 


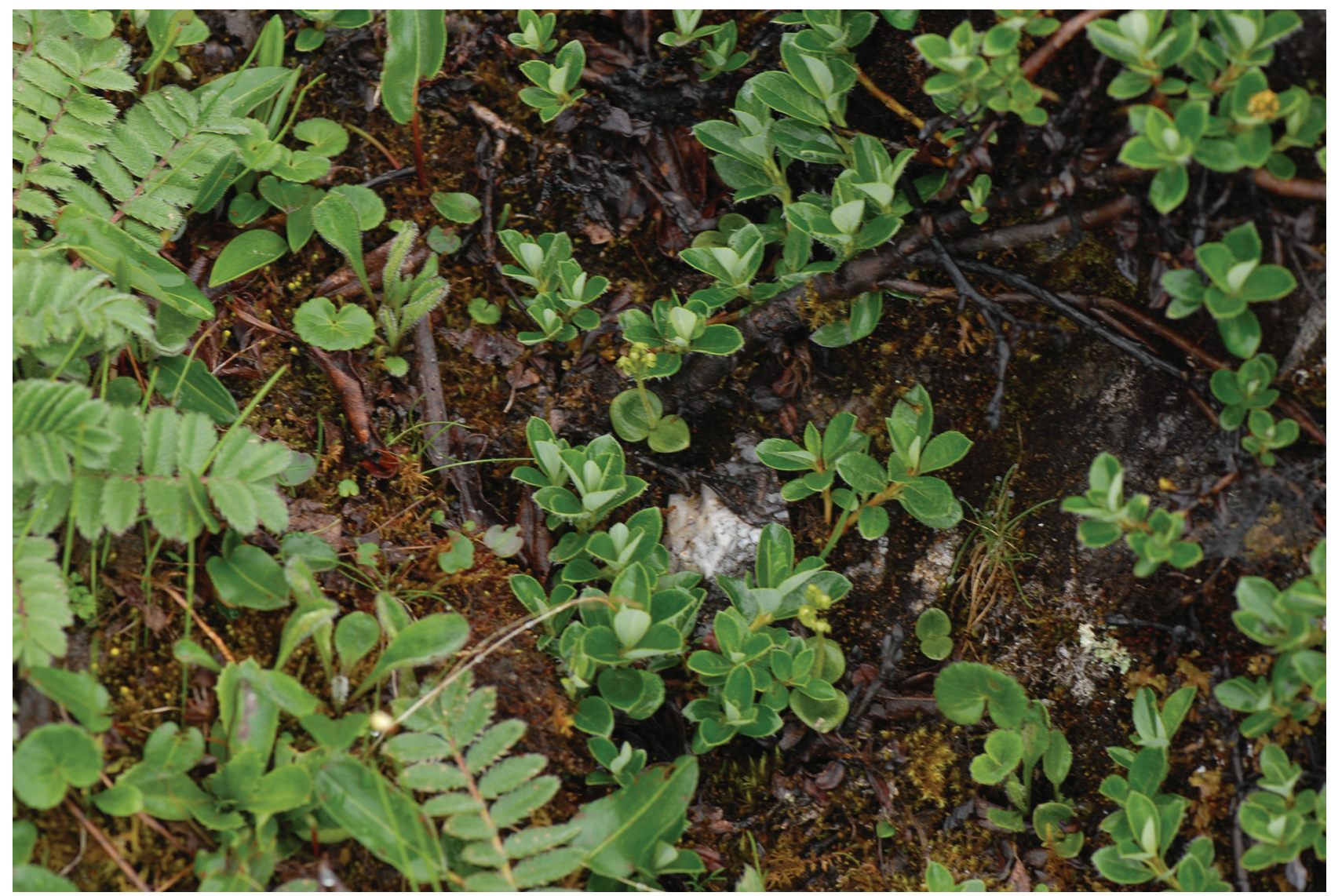

FIGURE 2. Habitat of Neottia bicallosa X.H. Jin (Photo by Jin, X.H.)

\section{Acknowledgements}

We are indebted to the officials of Chinese Forest Bureau and Yunnan Forest Bureau for their kind help during the fieldwork. This research was supported by grants from the National Natural Science Foundation of China (Grant No. 31107176, 31311120061) and Specific Funds of Traditional Chinese Medicine Industry (201407003).

\section{References}

Brown, R. (1813) Listera. In: Aiton, W. \& Aiton, W.T. (Eds.) Hortus Kewensis or, a catalogue of the plants cultivated in the Royal Botanic Garden at Kew, $2^{\text {nd }}$ edition, vol. 5. Longman, Hurst, Rees, Ormes and Brown, London, pp. 201.

Chen, S.C. (1981) Three new species of Listera (Orchidaceae) from China. Kew Bulletin 35(4): 759-761.

Chen, S.C. (1999) Neottia and Listera. In: Lang, K.Y. (Ed.) Flora Republicae Popularis Sinicae, 17. Science Press, Beijing, pp. $97-121$.

Chen, S.C., Gale, S.W. \& Cribb, P.J. (2009) Neottia. In: Wu, Z.Y., Raven, P.H. \& Hong, D.Y. (Eds.) Flora of China. Vol. 25. Sciences

Press, Beijing, in association with Missouri Botanical Garden Press, St. Louis, pp. 184-195.

Chen, S.C. \& Luo, Y.B. (2002) Additional notes on Chinese Listera (Orchidaceae). Novon 12(4): 438-440.

Guettard, J.É. (1754) Histoire de l'académie royale des sciences. Avec les mémoires de mathématique \& de physique. L'Imprimerie Royale, Paris, 374 pp.

Lindley, J. (1857) Contributions to the Orchidology of India. No. 1. Journal of the Linnean Society, Botany 1: 170-190.

International Union for Conservation of Nature and Natural Resources (2001) IUCN Red List Categories and Criteria, Version 3.1. IUCN, Gland, Switzerland and Cambridge, United Kingdom. Available from: http://www.iucnredlist.org/ (accessed: 19 Jan. 2014).

Pearce, N.R. \& Cribb, P.J. (2002) The Orchids of Bhutan. The Charlesworth Group, Huddersfield. 643 pp.

Pridgeon, A.M., Cribb, P.J., Chase, M.W. \& Rasmussen, F.N. (2005) Genera Orchidacearum, 4. Oxford University Press, Oxford, 672 pp.

Szlachetko, D.L. (1995) Systema Orchidalium. Fragmenta Floristica et Geobotanica Suppl. 3, 152 pp. 